\title{
Small Worlds in Canada and Europe: A Comparison of Regional Party Systems in Québec, Bavaria and Scotland
}

\author{
Dr Eve Hepburn, \\ School of Social and Political Studies, University of Edinburgh \\ Email: eve.hepburn@ed.ac.uk
}

\section{Introduction}

This paper explores the dynamics of regional party systems in a comparative analysis of three 'small worlds' in Canada and Europe. The analysis forms part of wider exploration of the enduring impact of Elkins and Simeon's (1980) book Small Worlds on approaches to political science. The paper draws primarily on Elkins' analysis of Canadian provincial party systems. His research revealed that there was a strong regional dimension to party competition and that 'parties were themselves divided along provincial lines as much as party lines'. Elkins recommended two paths of further research: greater in-depth analysis of regional systems, and a broader comparison across countries. This paper aims to meet both these requests.

Québec, Bavaria and Scotland are three regions nested within multi-level states. Each has a pronounced territorial identity and a strong regionalist party, factors that have contributed to an important territorial cleavage in political life. These cases have also been described as 'stateless nations' embedded in the larger structure of the state, presenting alternate worlds for political socialisation. As individual 'containers' of social attitudes and behaviour, these small worlds have distinctive party systems reflecting the efforts of regional parties to reflect the values of the electorate. The aim of this paper is to unpack territorial differentiation in Québec, Bavaria and Scotland by exploring the internal dynamics of party systems, and their integration into the state. It also modestly aspires to extend parts of Elkins and Simeon's thesis by introducing new research on party competition through the lens of multi-level politics, and by translating the Small Worlds thesis to a European context.

The paper begins with a review of recent European approaches to party behaviour in multi-level systems, before introducing the rich body of literature in Canadian political science exploring the organisation of parties along federal-provincial lines. In particular, it considers the methodological relevance of Elkins and Simeon's Small Worlds thesis for the analysis of regional politics beyond Canada. Three lines of questioning about regional party systems, which were originally posed by the authors in 1980, are then discussed in the context of present-day developments in Canadian and European territorial politics. Specifically, these questions deal with: (1) the (in)congruence of party systems and competition at the regional and state levels; (2) the adaptation of statewide parties to the regional level; and (3) the conduct of party competition on regional issues. These three indicators of distinctive political 'small worlds' are then explored in detail in each of the case studies. The final part of the paper compares party competition in multi-level political settings, and considers the continuing relevance of the Small Worlds thesis for the analysis of regional party politics in newly decentralising as well as established federal states in Canada, Europe and beyond.

\section{Parties and Multi-level Political Systems}

In the last few years, there has been a modest surge of academic enquiry into the operation of political parties in federal, devolved and decentralised states in Western Europe. Scholars have 
begun collecting empirical data on party organisational responses to the strengthening of regional government in cases such as Spain, Italy, Germany and the UK (Detterbeck and Renzsch 2003; Fabre 2008; Wilson 2008). Single or comparative case studies have emerged on the territorialisation of party organisations such as the Catalan Socialist Party (PSOE) and the Scottish and Welsh Labour parties (see Hepburn 2006; Hopkin and Bradbury 2006; McEwen 2004). Moreover, first steps have been made towards analysing the effects of state decentralisation on formal party structures (van Biezen and Hopkin 2004), the impact of devolution on electoral politics (Hough and Jeffery 2006), the mechanics of party systems at different territorial levels (Deschouwer 2003; Thorlakson 2006) and the strategies pursued by statewide parties in response to multi-level political dynamics (Detterbeck and Hepburn 2009forthcoming). These efforts to capture the complexity of party responses to state restructuring represent an attempt to unpack sweeping theories of 'nationalisation' of party systems and competition (Caramani 2004). Yet, although the territorial differentiation of party politics is now on the radar of European scholarship, there have been few efforts to systematically compare multi-level systems, or the small worlds nested therein. The very fact that European approaches to party organisational change are still in their infancy means that a broader comparative perspective is much welcomed and also needed.

Elkins and Simeon's 1980 book on Small Worlds in Canada marked a seismic shift in social scientific thinking on politics and territory. Their study provided a wealth of data that demonstrated the various ways in which politics has been informed by territorial factors. Hitherto, political behaviour was believed to be determined by social class interests, whereby functional diffusion across the state would lead to the ironing-out of territorial differences. Elkins, Simeon and their colleagues put to rest these long-dominant myths by providing a nuanced and complex picture of the Canadian political system that acknowledged the ethnic, linguistic, religious and regional diversity of the territory. Their study explored cleavage patterns, policy outputs, voting behaviour, political cultures and party systems at the provincial level. The latter issue was dealt with in a chapter by David Elkins, which challenged standardised accounts of Canadian party politics. His conclusion was that 'there is no national party system even at the federal level. Each party and each region is a small world' (Elkins 1980: 238).

This tradition in Canadian political science, of viewing politics through multiple territorial lenses, both preceded and followed Elkins and Simeon's study. Years earlier, Leon Epstein (1964) had written a comparative study of Canadian political parties, reflecting on the diversity and fragmentation of parties and party systems across provinces. Since then, Canadian scholars such as Andre Blais, R. Kenneth Carty, Fred Cutler, Munroe Eagles and Elisabeth Gidengil have pioneered work on political cultures, policy making, voting behaviour, political socialisation, elections, party systems and competition at the provincial level in Canada. The task now is to extend and review these approaches to Canadian multi-level political organisation in a broader comparative context. For 'small worlds' are not unique to Canada as the structural basis of political behaviour; such worlds also exist as spaces for collective action and identities in countries throughout the globe. Nowhere is this truer than in Europe, historically understood to be the haphazard amalgamation of city states, localities and villages rolled into the most victorious, expansionist nation-state of the day (Tilly 1975). In light of recent structural transformations resulting from European integration and decentralisation, scholars have argued that the regions have re-emerged as important political and economic actors in Europe (Storper 1995; Keating 1998; Hepburn 2008). This development has major implications for the study of political behaviour, not least the operation of parties in post-sovereign multi-level orders. European scholars have much to learn about the role and implications of small worlds in larger 
states. This paper makes a start by applying some of Elkins and Simeon's research questions to cases of regional party politics in Europe, and vice versa, by extending some European-based analyses of party organisation and territorial competition to Québec.

\section{Small Worlds and Regional Party Systems}

Little has been written about the characteristics of regional party systems and competition in a cross-national comparative framework. This may be explained by the tendency to perceive ideology as constituting the fundamental axis upon which parties compete, and the belief that regional political behaviour and competition tends to replicate that of the state (Sartori 1976; Maor 1997). Political parties are commonly classified and differentiated from one another by their location on a left-to-right spectrum (Elkins 1980: 212). Downs (1957) maintained that parties compete by taking diverging ideological positions along a set of issue dimensions, whilst Sartori (1976) understood political parties as strategic actors who seek to translate ideological cleavages into electoral support. Sartori was aware of the bias inherent in the left-right imagery, and he later also considered religious, ethnic and linguistic dimensions in determining party competition (Sani and Sartori 1983). But these cleavages were believed to be secondary to ideology, limited to isolated segments of the electoral market.

A growing body of literature has challenged the Downsian/Sartorian view of party competition by demonstrating how political activity has often pivots around issues of culture, language, boundaries and self-determination (Lynch 1996; De Winter and Tursan 1998). It has been argued, in the footsteps of Rokkan and Urwin (1983), that territory provides an important framework for systems of political interaction. The emergence of regionalist movements seeking to overhaul state structures demonstrates that the centre-periphery cleavage has not weakened. Moreover, the trend towards decentralisation in OECD states means that the substate electoral arena has gained in importance as a focal point for territorial interests (Jeffery 1997). At this level, statewide parties must operate in a peculiarly regional context, and compete on regional issues. The nationalist party is not the only one claiming to protect or advance territorial interests. Shifts in the territorial distribution of power to regions have led to the 'denationalisation' of party systems, and that parties must respond to substate challenges (Hopkin 2003). This has led to intra-party conflict as different levels of parties diverge in the areas of policy development, campaigning, and their activities in public office. In particular, regional branches must adopt territorial strategies to defuse the threat of secession in cases where a nationalist party exists.

The rest of this paper will assess the ways in which political parties have responded to the challenges of multi-level political systems in the small worlds of Québec, Scotland and Bavaria, how their activities affect and are structured by the party system at different levels, and how they compete on the territorial dimension. The cases have a good mix of 'most similar' and 'most different' research design. Québec, Scotland and Bavaria all constitute institutionalised regions embedded in the larger structures of multi-level states. Each regional government has primary legislative powers over a range of policy areas including education, culture, infrastructure and planning, and regional electoral arenas have become important spaces for party competition. These regions have also been characterised as stateless nations, owing to the existence of a strong territorial identity supported by regional civic institutions, a distinct political culture and the successful political mobilisation of territorial interests by regional parties. There are also differences, however, resulting from the structure of the states in which the 'small worlds' are embedded, the capacity of the region to legislate, relations with the state, the dominance of political ideologies and the salience of different territorial issues and interests. These factors, amongst others, permit us to tease out differences and to account for sources of cross-national 
variation. The next part of the discussion applies a number of research questions posed by Elkins and Simeon to the contemporary conduct of territorial politics in Québec, Scotland and Bavaria.

\section{Regional Party Systems}

One of the key questions that Elkins and Simeon asked with regard to the political composition of small worlds was: 'how do provincial party systems - as defined by such factors as numbers, competitiveness, ideology - differ among themselves or from the national party system?' (1980: $\mathrm{xv})$. This section examines the degree of symmetry between the regional and state levels to understand and explain the dynamics of multi-level party competition. In each of three cases it is argued that there has been an increase in asymmetrical party competition between the region and the state level. This primarily owes to the existence of an electorally or politically successful nationalist party seeking greater constitutional, but it is also determined by other differences, including the distribution of support for parties across states and the extent to which they are locally embedded within the region.

\section{Québec in Canada}

The Canadian party system has undergone a series of major re-alignments throughout the postwar period, the last of which unequivocally demonstrated the regional nature of Canadian politics. From the late 1950s onwards, scholars have described Canada as two-plus party system, with the Liberals and Conservatives competing for the majority of votes. Some scholars were even tempted to call Canada a one-party system because of the predominance of the Liberal Party, which held office near-continuously throughout this period, earning it the title of 'natural governing party' (Epstein 1964; Carty 2006: 826). In addition, the NDP represented an important 'third party', with particular strength in Western Canada. This system imploded in 1993 when the three main parties saw their vote collapse. From this point, Canada became a multi-party system at the federal level (Carty et al 2000). New parties emerged, including the Bloc Québécois and Reform/Canadian Alliance, with strong regional support bases in Quebec and Alberta, respectively. The potential threat of the new parties reached fruition in 2006, when the Progressive Conservatives amalgamated with the Alliance, forming the Conservative Party of Canada and winning the federal election that year.

Since 2006, there has a four-party system in Canada - Liberals, Conservatives, NDP and Bloc Québécois (Eagles and Carty 2003). Yet aside from the Liberals, each of the other parties is strongly regionally based (Gidengil et al 1999; Carty 2001). For instance, the NDP appeal was first confined to the Western provinces, but is now strongest in urban centres of Ontario; the Reform/Alliance party was very much a Western party with a solid base in Alberta; whilst the Bloc Québécois was formed to represent Québec interests in the federation. Some commentators have even argued that the Liberals have even become more regionally based, through their overreliance on electoral support in Ontario (Carty 2006: 826). As such, there is no one single party system in Canada, but rather 'shifting, but distinct, regional party systems' that give primacy to regional interests (Carty 2001). Each province has a different and highly regionalised choice of parties in federal elections (Gidengil et al 1999), and in provincial elections, there is an even greater choice of parties. Yet "no other provincial party system in Canada is as distinct from the federal system as Québec's' (Rayside 1978: 500).

From the late 1960s until the 1990s Québec has had a two-plus system, whereby the Liberal Party and the Parti Québécois together won at least $85 \%$ of the vote in every provincial election since 1973 (Tanguay 2004: 223). Québec was a Liberal stronghold until it was faced with the birth and rise of the PQ since 1968. Since then, the PLQ has alternated in power with the 
PQ, commanding an average of $45 \%$ of the vote in provincial elections from 1960-2007. The PQ, which has sought various forms of independence for Quebec, won impressive electoral support in its early years. It held office from 1976-85, and 1994-2003, implementing a series of reforms designed to preserve Québec's unique cultural identity and status, including two unsuccessful referendums on sovereignty-association in 1980 and 1995. Meanwhile, Conservativism had not been well represented in Québec since the 1960s, with the decline of the nationalist Union Nationale. However, this changed with the rise of the right-wing nationalist Action Democratique $d u$ Quebec. In the 2007 provincial elections, the ADQ became the official opposition, relegating the PQ to third-party status. The result marked the transformation of Québec politics to a threeparty system (Bélanger 2008). Finally, the NDP in Québec has historically been weak in provincial elections, and after separating from the federal NDP, it merged into the Union des forces progressistes (UFP), which garnered only 1.0\% of the vote in the 2004 election.

\section{Scotland in the UK}

Party competition in the UK has been influenced by the historical impact of a two-party system, with each party representing opposing ideological poles - Conservatives vs. Liberals during the nineteenth century, and Conservatives vs. Labour in the twentieth century. In the 1970s and 1980s this system came under pressure by the rise of smaller parties, including the newly merged Liberal Democrats, the Green Party and minority nationalist parties in Scotland (Scottish National Party) and Wales (Plaid Cymru). The LibDems became 'third' party in UK elections, though the single plurality electoral system used for statewide elections favours the two bigger parties. However, the alleged 'two-party' system in the UK was challenged with the introduction of constitutional reforms in the late 1990s.

In 1997-99, the UK was transformed from being a centralised unitary (or union) state to a devolved state. In a referendum in 1997, the Scottish electorate voted overwhelmingly $(74.3 \%)$ for a Scottish Parliament, which was granted extensive legislative powers. Devolution accentuated the distinctiveness of party system in Scotland. Although class is a relevant feature of voting in Scotland, there is a strong territorial dimension, and when parties in Scotland did not fully represent the Scottish interests this resulted in electoral deviations on either side of the border. Since 1959, Scottish voting preferences diverged from the rest of the UK, heralding the decline of Scottish Unionism, which came to a head during the 'Thatcher years' of 1979-1990, Labour's consolidation of being Scotland's favourite party, and the rise of the SNP. Since the 1970s, the SNP has successfully competed in a four-party system with Labour, the Liberal Democrats and the Conservatives, taking between $15-25 \%$ of the vote until the 1990s. From this time, the party system in Scotland differed from the rest of the UK (Brown et al 1998).

Since devolution, which introduced an additional member system (AMS) for electing the regional parliament, Scotland has had a multi-party system. Six parties compete on the Left of the political spectrum (the Scottish National Party, Scottish Socialist Party-SSP, Solidarity, Labour, the Scottish Green Party and the Liberal Democrats) whilst the Conservatives compete on the Right. On territorial matters, four parties support independence (SNP, SSP, Solidarity, Scottish Greens), two parties support devolution (Labour, Conservatives) and one party supports federalism (LibDems). In 1999, the SNP won $28.7 \%$ of the vote, and became official opposition in the Scottish Parliament. In 2007 it won 32.9\% of the vote and formed a minority government. That year, nationalist parties were also elected to devolved parliaments in Wales (Plaid Cymru) and Northern Ireland (Sinn Fein), heralding a new type of politics in the UK, and putting considerable strain on the devolution settlement. 


\section{Bavaria in Germany}

Before German unification in 1990, federal and regional (Land) party systems were largely symmetrical. Although the parties varied in regional strength - most particularly a conservative South and social-democratic North-West - the same pattern of party competition applied across the country. The Christian Democrats, Social Democrats and Free Democrats, which together held $97 \%$ of the vote in national elections from 1961-1980, were the only relevant players in the Länder and at the federal level. Smaller regionalist had disappeared from the Land parliaments after the 1950s. This two-and-a-half system changed in the 1980s, when the Green Party entered the Bundestag and most regional parliaments. At the point, patterns of competition moved towards a two-bloc logic, with the CDU/CSU-FDP on one side, and the SPD-Greens on the other. However, regional party competition has become more distinct since German unification. There is now a clearer divide between East and West Germany with respect to the political relevance of specific parties. Whilst there is a five-party system at the federal level, at the regional level four parties compete in the West, and three parties compete in the west (CDU, SPD, PDS/Left Party).

The exception to these party system realignments occurred in Bavaria, which has been run by the autonomist Bavaria Christian Social Union (CSU) since 1946. According to James (1995: 1), 'the Free State of Bavaria has operated almost as a system within a system'. Although the traditional cleavages of German politics apply, there is an important territorial dimension to party competition in. Bavaria's political system, which is dominated by the CSU, has been able to maintain its distinct traditions and political culture that mark it out from the rest of Germany. The CSU has governed Bavarian near continuously since 1946, without coalition partners since 1966, and with a two-thirds majority since 2003. It is also the largest party in Bavaria at federal elections. But although the CSU is part of the national political camp of Christian Democracy in all-German terms, in Bavaria the CSU is a clearly regionalist party, mobilizing claims to special treatment around the concept of Heimat (nation) and seeking autonomy for Bavaria in Germany.

The nationalist and federalist stance of Bavaria's 'party of state' has had a significant impact on party competition in Bavaria. Regional branches of the Social Democratic Party, the Free Democrats and Greens have all acknowledged the need to take a more pro-Bavarian stance in order to succeed electorally, and have adopted more distinctly territorial identities and policies. Yet these strategies have remained weak, and the position of the CSU's main opponent in Bavaria, the SPD, is described as 'hopeless' by the foremost thinker on Bavarian politics, Alf Mintzel (1999: 115). Its best election result was in 1966, when it took $35.8 \%$ of the vote in the Landtag elections. In the 2002 Landtag elections, the SPD received only $18 \%$ of the vote. Even then, this was significantly better than the other opposition parties' results - the Bavarian FDP has since failed to win more than $5 \%$ of the vote since 1994, whilst the Greens marginally increased their share of the vote from $5.7 \%$ in the 1998 Landtag election to $7.7 \%$ in 2003 . The weakness of opposition regional branches of statewide parties in Bavaria may be partly explained by their lack of a strong Bavarian party identity or perceived ability to defend Bavarian interests.

\section{Statewide Party Adaptation}

One of the key questions posed by Elkins and Simeon in their book concerned the changing role of parties in politically, socially and culturally diverse states. They enquired: 'Can the parties act as nationally integrative institutions? Can they win support nationally, or are they confined to some regions...?' The next section will address these questions by exploring how statewide parties have responded to the challenges of operating within and across multiple territorial levels. It examines the organisational and programmatic adaptation of the main statewide parties: 
including the Liberal, Conservatives and NDP in Québec; Labour, the Conservatives and the LibDems in Scotland; and the SPD, FDP and Greens in Bavaria.

\section{Québec}

It has been argued that Canadian statewide party organisations are 'essentially no more than a federation of autonomous provincial bodies' (Dawson 1957: 529). Though this statement was written in the 1950s, half a century on it could not be more pertinent. The Liberals, Conservatives and NDP strive to be 'national' parties, but are increasingly challenged by regionally based parties, not least in Québec. In response to the increased regionalization of the vote, they have adopted different organisational structures, leading to a 'disentangling' of the federal and regional parties (Carty et al 2000: 23). But at the same time, there is still strong party cohesion in Canadian parties, and policy cooperation is facilitated through a strong parliamentary party caucus. This would indicate that the federal and provincial parties share the same outlook and priorities. Yet, there have been some exceptions, most notably in Québec, where 'relations between federal and provincial parties have been most consistently strained' (Rayside 1978: 500).

The Québec Liberal Party (PLQ) has always been relatively autonomous. Its roots can be traced back to the Parti Rouges representing 'Canada East' prior to confederation in 1867, and despite the formal amalgamation of the party with the pan-Canadian Liberal Federation, the PLQ has always had a separate voice, greater autonomy and special treatment within the Liberal party. For instance, the PLQ retained a 'Québec leader' in the cabinet, Québec always held one of the co-Chairman positions on the national campaign committee, and the PLQ only marginally engaged in the functioning of the central office (Rayside 1978: 505). In 1964, following decades of deteriorating federal-provincial relations, the PLQ formally 'disaffiliated' itself from the Liberal Federation under the stewardship of Jean Lesage. And until 1975, Québec was the only province in which the federal and provincial Liberals were formally separated into two extraparliamentary organisations, with few ties between them.

The separation of the PLQ from its federal brethren was the product of a number of factors. Four years earlier, the party had won office in Québec after 16 years of conservative rule. The PLQ undertook sweeping governmental reforms and championed a new political vision of Québec. In order to best serve the interests of Québec, it was argued that Liberal Party should exercise complete autonomy over policy and campaigns. Moreover, Québec-Ottawa relations were frayed over the federal Liberal retreat from the province following a deal with the Unione Nationale. Following separation, the Liberals pursued a strategy of moderate nationalism from a federalist perspective, but which was not beholden to federal interests. This was particularly important during the period of Pierre Trudeau's premiership when his vision of a multicultural Canada sat uneasily with the PLQ's advocacy of Québec as a distinct society (Carty 2001). Indeed, party relations have become strained on regional issues, particularly since the Meech Lake Accord in 1990. The failure of the negotiations resulted in the radicalization of the PLQ, and its leader Robert Bourassa declared that 'Québec has always been, is now and will always be a distinct society, free and capable of taking responsibility for its own destiny and development' (quoted in Tanguay 2004: 229). The party thereafter demanded a massive decentralization of federal powers to Québec and proved that it too was capable of playing the nationalist card.

Conservativism in Québec has tended to come in strongly nationalist guises. The Union Nationale dominated Québec politics from the 1930s up until the death of party leader Maurice Duplessis in 1959. The party had secured a 'non-aggression pact' with the Catholic Church and anglophone economic elites, as well as an entente cordiale with the Progressive Conservatives in Ottawa so that they did not organize in Québec. Yet the hegemony of the UN was increasingly 
questioned with changes in the social fabric of Quebec, and although the UN won a last term in office in 1966-70 it was unable to recover from splits between its nationalist and federalist wings (Tanguay 2004: 223). A different sort of right-wing nationalism emerged two decades later. The ADQ was formed in 1994 by nationalist members of the PLQ who were disappointed with the federal Liberal government's failure to recognize Québec as a distinct society. The ADQ has since been successful in winning traditional rural electoral districts that were once considered the base of Union Nationale support. Given its provincial roots, the ADQ is only loosely affiliated to the federal Conservative Party. Yet the ADQ did endorse Harper's Conservatives in the 2006 election, creating speculation about possible ties.

The New Democrats are the most decentralised of the Canadian parties, constituting a federation of powerful provincial organizations. However, in Québec, the French-English linguistic divide had confined the NDP to working-class English-speaking Canada (Carty 2001). Although the NDP supports Québec's right to self-determination, they oppose further devolution of financial and political powers to the Québec National Assembly. This position has made the NDP an unpopular choice in provincial politics. Moreover, the Québec wing of the NDP has had a history of difficult relationships with the federal party. The Québec branch, which was founded in 1963 to contest only federal elections, seceded from the NDP in 1989 and changed its name to Parti de la démocratie socialiste (PDS) in 1994. The provincial Socialist Party of Québec became defunct in 1979. After a poor electoral showing in the 1998 federal election, the PDS

subsequently joined the Québec-based movement Union des forces progressistes (UFP), which in turn merged into Québec solidaire in 2006.

\section{Scotland}

Since devolution, statewide parties in the UK have decentralised their Scottish branches to enable them to compete with a resurgent political nationalism. But even before then, Scottish parties had distinct features and personalities that marked them out from their British counterparts. Although British parties have generally been treated as 'unitary' actors in party scholarship, parties in Scotland have often issued distinct manifestos, taken specific policy lines and advances different autonomy solutions to Scotland's constitutional question that have diverged from the statewide party line (Hepburn 2006).

Traditionally, the Scottish Council of the Labour Party had constituted administrative branches of the unitary UK Labour Party. This 'council' enjoyed little more autonomy than English county branches, but a number of developments forced Labour to reconsider its centralist organisation. First, Labour needed to respond to the North-South polarisation of Labour and Tory support that peaked during the 1987 election. Second, there was a strategic need to combat the resurgence of political nationalism in Scotland, which Labour did by supporting a programme of devolution. And third, there were tensions emanating from its Scottish 'regional council' for more autonomy. A breakaway party was formed in 1975 that sought to fuse socialism with nationalism, and other factions within the party have been vociferous in their calls for greater Scottish autonomy and a more distinctive identity (Mitchell 1996; McEwen 2004). Scholars have called this the 'tartanization' of Scottish Labour, as it becomes more nationalist in its policies and strategies (Geekie and Levy 1989).

In 1994, a degree of autonomy was granted to the Scottish branch, which changed its name to the Scottish Labour Party. The SLP had its own headquarters, executives and annual conferences, and there was little interference in the day-to-day running of the Scottish party. Yet it also had little decision-making power, as party policy, candidate selection rules and campaign strategies were decided by the British leadership. In the early years of devolution, Labour 
transferred a number of powers to the Scottish branch, including control over internal party decision-making, devolved campaign strategies and policy development (Bradbury 2006). The latter function allowed Labour to develop a policy programme more attractive to Scottish voters, which was important in the context of 'New Labourism', a middle-England strategy that failed to resonate north of the border. Scottish Labour has since diverged with UK party policy on issues of healthcare and higher education, implementing distinctly non-New Labour policies when in power at the devolved level from 1999-2007.

The British Liberal Democrats, in line with their constitutional preferences, constitute a federal party. Prior to devolution, the party in Scotland enjoyed a great deal of autonomy. It had their own party headquarters, executive, annual conferences, and were free to develop their own policies, internal procedures and select their own candidates. In this sense, the LibDems were the best prepared out of all the main statewide parties to meet the challenges of multilevel governance. With devolution, the party simply adapted its federal arrangements to the new constitutional settlement. The British leadership had no desire to control these procedures; instead, the Scottish party was encouraged to develop their own initiatives and adapt their policies to their governing coalitions with Labour in Scotland 1999-2007.

The Conservative Party, despite its distinctive roots in Scotland, was in the years leading up to devolution perceived as an English, anti-Scottish party (Seawright 2002). Followings its election defeat in 1997, where it failed to elect any candidates in Scotland, the party struggled to accommodate the territorial dimension in its organisation and policies. The party was highly centralised, owing to former UK Party Leader Margaret Thatcher's efforts to bring the Scottish branch into line as a 'regional unit' by assuming control over its personnel, finance and political office, so that ultimate authority was exercised by the British leadership. Previously, the Scottish party, known as the Scottish Unionist Party 1912-1965, had been constitutionally separate from its English counterparts. Yet, sections of the Conservative party in Scotland also harboured a desire for greater autonomy (Bradbury 2006). Following devolution, the Scottish party held an internal review on how to respond organisationally to the devolved legislatures and to win back electoral support. The outcome was a decision to transform the branch into a more 'Scottish' party by granting it constitutional independence, though it was still affiliated to the British party and exhibited a Conservative identity. This allowed the party to control procedures for candidate and selection, campaign strategies and policy programmes. The result was a confederal relationship between the Scottish and British parties, though the Scottish party is still strongly tied to the British party in UK elections.

\section{Bavaria}

Whilst all of the German political traditions are represented within Bavaria, each has taken on a peculiarly Bavarian hue. In particular, the creation of the Christian Social Union demonstrated a desire for organisational and programmatic independence from Christian Democrats in the rest of Germany so that it could represent Bavarian interests. The CSU was part of a long tradition of Bavarian regionalist parties. However, it did not seek to restrict its activities to the regional political arena. Instead, it negotiated an agreement with the Christian Democratic Union in the years 1947-9, whereby the CSU was able to participate in federal politics as part of the Christian Democratic parliamentary group and fill Cabinet posts in CDU-CSU governments, whilst at the same time maintaining its full autonomy. This autonomy was manifested through separate party programmes and congresses, organisational and membership structures, and the existence of a CSU Landesgruppe in the Bundestag. Both parties agreed not to contest elections outside of their territories (Bavaria for the CSU and the rest of Germany for the CDU) and the CSU became 
known as the sister-party to the CDU. There is a common party caucus of both parties in the Bundestag and a permanent exchange of political positions among the leading politicians of both parties. As a result of this agreement, the CSU developed an institutional and political 'dual role' as an autonomous Land party with special federal characteristics (Mintzel 1990: 92).

Parties representing the competing ideologies of socialism and liberalism in Bavaria have failed to pose a major threat to the governing CSU. Although Land branches have tried to strengthen their Bavarian identities, they are generally perceived as affiliates to Berlin. The Bavarian Social Democrats have long exhibited a separate identity from the rest of the party, due to their long-standing sympathy with the need to preserve Bavaria's unique identity, in addition to the challenge of operating within a conservative political context (Unger 1979; Ostermann 1994). The Bavarian branch preceded the transformation of the federal party into a 'catch-all' party in 1956 in response to the strongly anti-Left political landscape of Bavaria. Whilst regional branches of the SPD were being integrated into the federal executive and directed by the centre, thereby strengthening policy cohesion, the Bavarian SPD was allowed to constitute itself as a Landesverband (regional association), which allowed for a degree of policy divergence. There were also further reforms in 1990, when the branch achieved Land party status and calling themselves 'BayernSPD' instead of 'die bayerische SPD'.

The FDP has been equally hampered by its perception as a Bavarian 'affiliate' of Berlin and by the federal party's opposition to regional patriotism. Because of its post-war affiliation with the Christian Democrats at the federal level, the FDP has been more reluctant to criticise the CSU at the Land level, making it an ineffective opposition force. Moreover, the FDP has suffered because of its unwillingness to develop a strong 'Bavarian' profile for the party as regional pride is associated with exclusivity. Yet the party has also acknowledged that it must appeal to the Bavarian identity to win more votes. Finally, the Green Party won their first seats in the Bavarian Landtag in 1986. Some scholars argue that the Greens should be considered less an ecological movement and more of a protest movement against the 'unholy trinity' of the Bavarian state, the CSU and the Catholic Church (Mintzel 1990: 172; James 1995). However, the party has been slow in committing itself to a specifically Bavarian agenda. In the 1990s, following internal discussions, the party decided that the regionalisation of Green parties elsewhere was working so well that they too would become more Land-focused. This involved the creation of policies that would appeal to the strongly patriotic and conservative Bavarian electorate.

\section{Party Competition on the Ideological/Territorial Axis}

In their book, Elkins and Simeon identified a particular constraint in classical thinking on party competition that prohibited a full account of regional dynamics of party competition. This was the tendency to view class and regional politics as antagonistic (1980: xiii). Elkins went on to argue that 'there is some tendency to use the left-right dimension to structure perceptions of the party systems in Canada, but other dimensions must also be at work...' (1980: 231-2). Elkins plotted the left-right dimension against the French-English dimension in the case of Québec in order to accommodate the specific nature of party competition there (ibid: 235). But I would argue that the main 'secondary' line of competition in Québec and other regions is the 'territorial' dimension - a broader concept than language that accounts for party views on region-state relations. So far, efforts to examine how regionalist parties compete with statewide parties have been foiled by the tendency to focus on ideology as the critical axis upon which parties compete, and self-determination as the main issue of competition for nationalist parties. The following section will make a first attempt at charting party positions on the territorial and ideological axes of competition, to give a more robust account of the organizing principles of the party systems. 


\section{Québec}

Scholars have often pointed to the unprogrammatic nature of the main national parties in Canada (Smiley 1972: 96). The ideological agility of the Liberals and Conservatives means that parties tend to competing over the centre ground on 'valence' issues (Stokes 1963; Elkins 1980: 214). In federal terms, only the NDP has articulated a strongly class-based programme, and has rejected pressures to develop a 'third way' platform a la Tony Blair (Carty 2001). In Québec, however, the situation is rather different. The existence of a left-leaning nationalist party has created a more ideologically, and territorially, bipolar system in Québec. Since the late 1960s, party competition pitted the social-democratic, independence-seeking Parti Québécois against the freemarket, federalist Québec Liberal Party. It was not until the 1990s that Québec voters backed a more extreme right 'third' party in provincial politics. The Left, meanwhile, is hugely underrepresented and the former NDP-USP remains a minor force.

This analysis represents an ideology-based interpretation of party competition. But according to some scholars, partisan competition in Québec 'still centres on the unresolved question of Québec's constitutional status' (Tanguay 2004: 222). The territorial dimension is key to understanding party competition in Québec. Until the mid-1990s voters had a choice between two options on the constitutional issue: either a form of independence/sovereignty-association as espoused by the PQ, and moderate reform of the status quo as represented by the Québec Liberal Party. Burgeoning support for the Action Democratique du Québec from 1994 onwards indicated that a sizable number of voters wanted a third way between separation and the status quo (Tanguay 2004: 235). ADQ success also means that there is now a large left-leaning nationalist party (PQ) and also a growing neoliberal nationalist party (ADQ) operating in Québec. Yet the ADQ's position is 'soft nationalist' (Keating 1996), alternating between support for independence and greater recognition of Québec nationhood within Canada. Based on this analysis, the positions of Québec parties on the territorial and ideological dimensions are shown in Figure 1. The left-right continuum is plotted against a 'territorial' continuum, ranging from independence to integration within the state. ${ }^{i}$

Figure 1: Two-dimensional representation of the party system structure in Québec

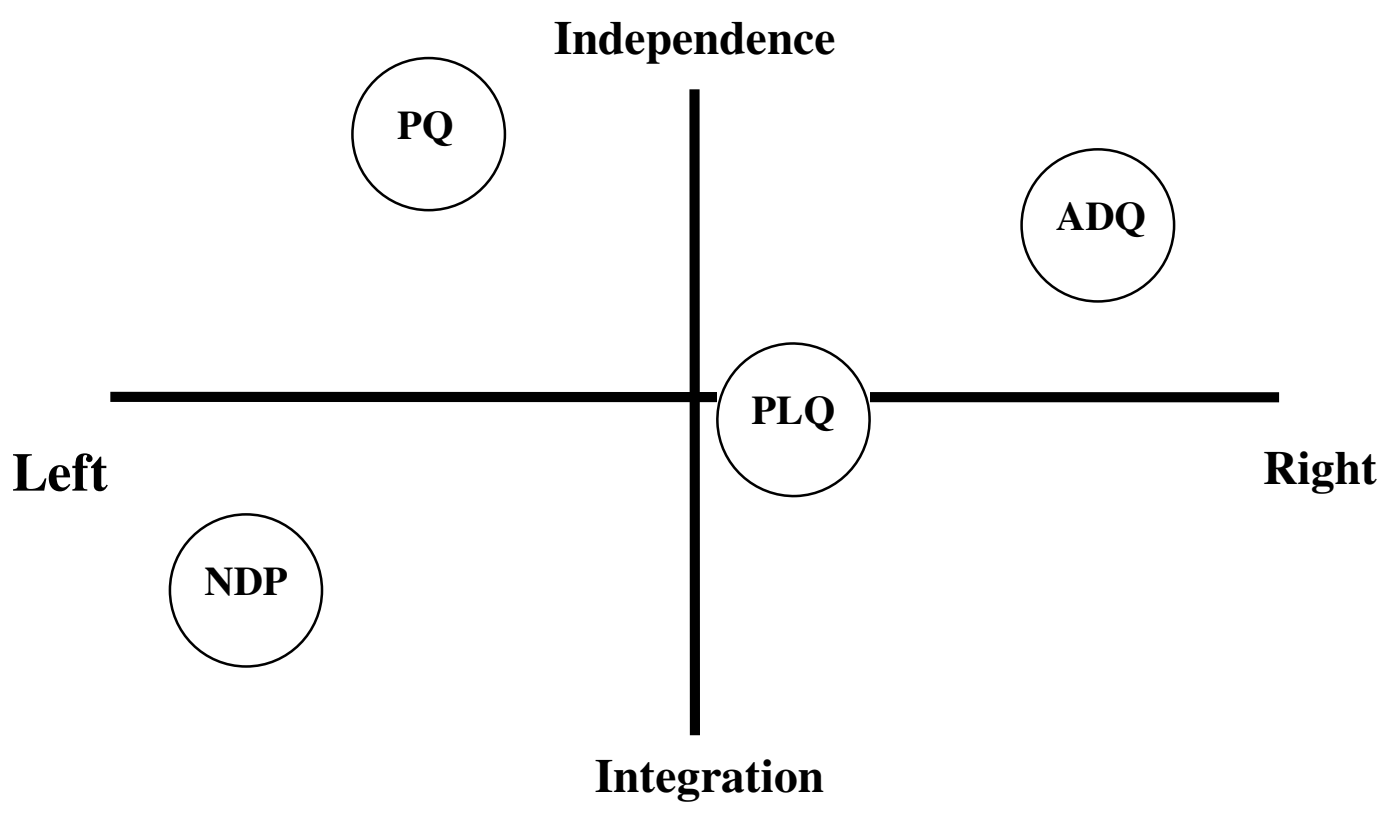




\section{Scotland}

Party competition in Scotland tends to take place on one side of the political spectrum, whereby six out of the seven main parties may be classified as 'centre-left' (Labour, Solidarity, Scottish Socialist Party, SNP, Scottish Greens and the SNP). Because of this, party positions on welfare issues in Scotland often converge. On territorial issues, however, parties have continuously moved back and forth on the issue of Scotland's constitutional future. In 1997, the Conservatives were the only party in Scotland not supportive of more constitutional powers in Scotland, whilst in 2007 Labour in Scotland held this isolated position by refusing to expand the Scottish Parliament's powers. The Conservatives and Liberal Democrats in the meantime have pressed for more fiscal powers. In the 2007 Scottish parliamentary election, parties were polarised on the territorial dimension, between the 'Unionists' (Labour, LibDems and the Conservatives) and the 'Nationalists' (SNP, Greens, Socialists and SSP).

As nationalism has become an increasingly important dimension of party competition, this has caused the two main parties to compete for the 'centre ground' over both policy and territorial issues. As Labour moved to support Scottish self-determination vis-à-vis devolution in the late 1980s, and the SNP moved to a more clearly social-democratic position in the early 1990s, it became apparent that both parties were fighting for the same vote. Their close-knit positions are clear in Figure 2. Most parties are situated in the top left quadrant, supporting greater autonomy for Scotland couched in left-wing terms. The Scottish Conservative Party represents a lone right-wing voice in Scottish party politics, and to date, there has been no successful right-wing nationalist competitor to the SNP.

Figure 2: Two-dimensional representation of the party system structure in Scotland

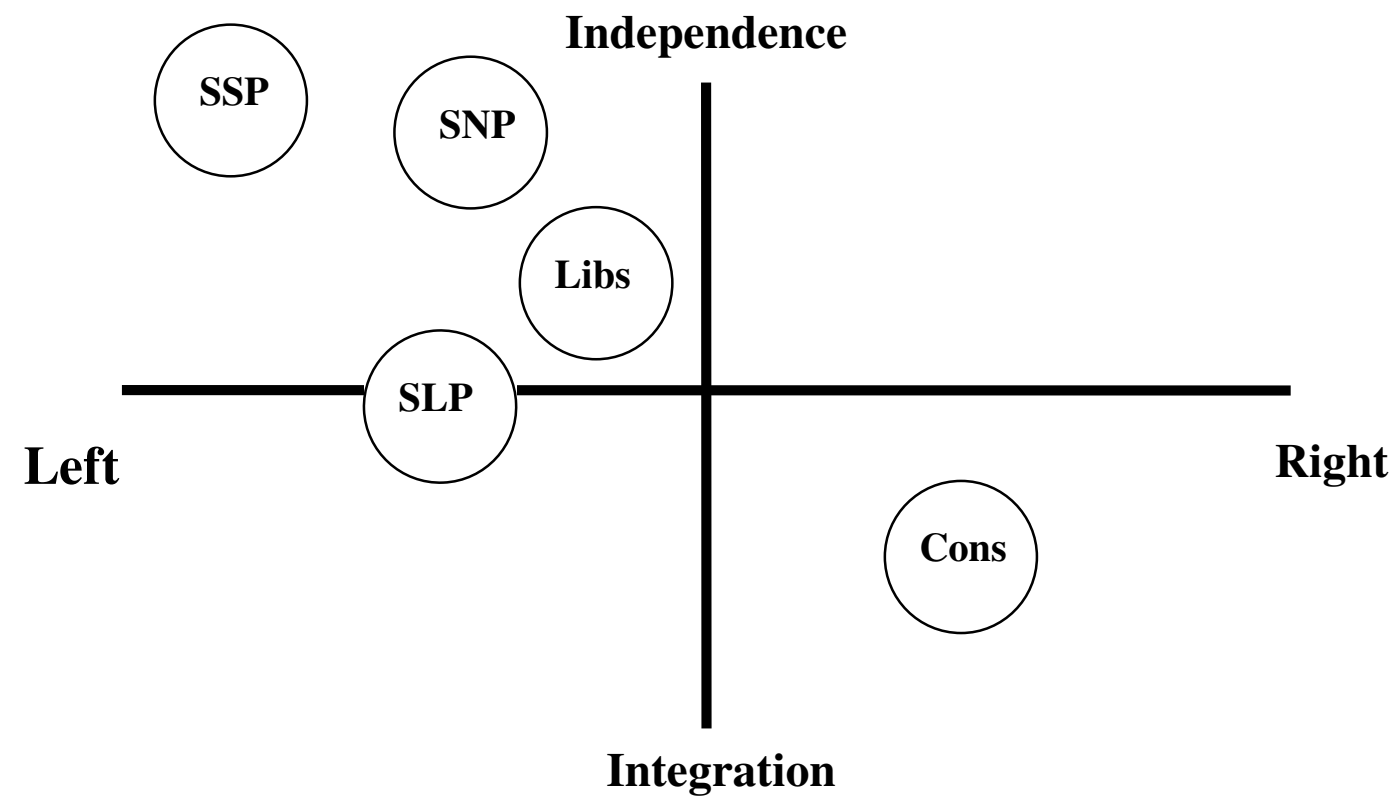

\section{Bavaria}

In Bavaria, party competition takes place on the right of the ideological spectrum owing to the hegemonic position of the Christian Social Union in Land politics. The left, represented by the Social Democrats, rarely take more than $20 \%$ of the vote, whilst the Greens, which make their 
appeal to both rural conservative and urban left-leaning supporters in Bavaria, take less than $10 \%$. The ideological centre-ground, represented by the Free Democratic Party (FDP) is very small in Bavaria, with the party taking less than $5 \%$ of the vote.

Scholars have agreed that, just as important as the ideological dimension in Bavarian party politics, the territorial dimension is central to understanding the strength of the CSU. In fact, the main political traditions in Bavaria have been identified as 'Catholicism and separatism ('nationalism' might not be too strong a description)' (Padgett and Burkett 1986: 114). On the territorial dimension, the pro-autonomist CSU is pitted against the pro-federalist opposition parties, the SPD, FDP and Greens. Nationalism is associated with the right, further typified by the micro-party Bavarian Party (Bayernpartei), an independence-seeking nationalist party that once took up to $30 \%$ of the vote in the 1950 s, but which has been reduced to less than $5 \%$ since then (Unger 1979; Hepburn 2008). There has been no development of a left-wing nationalist movement. Although the SPD in the past has sought to portray itself as a Bavarian party proud of its historical and cultural heritage, this tendency has been stifled by the anti-particularism of the federal SPD. As such, Figure 3 reveals that there is a right-nationalist confluence on one hand (CSU, BP), and a left-federalist confluence on the other (SPD, Greens), with the FDP floating in a centre-right, anti-regionalist space.

Figure 3: Two-dimensional representation of the party system structure in Bavaria

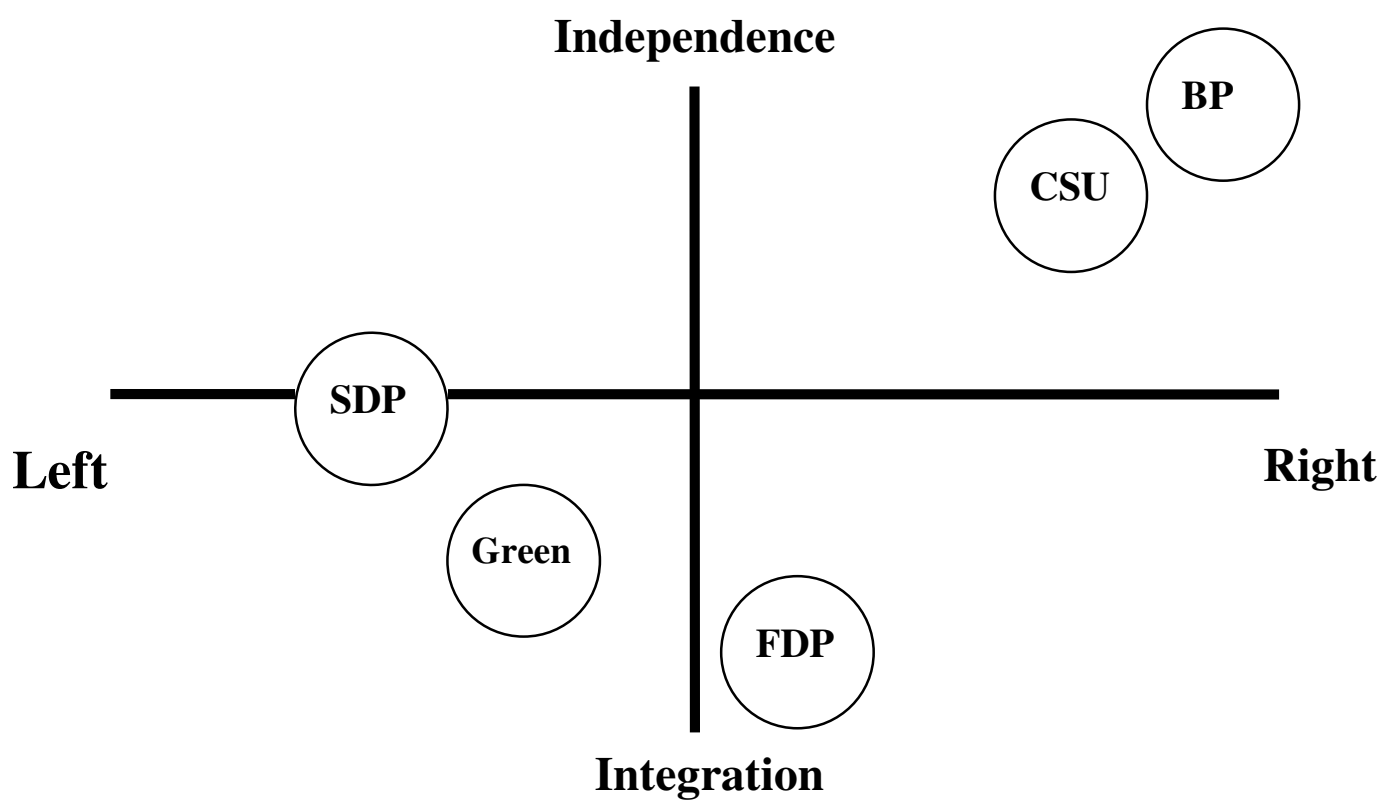

\section{Conclusion}

This discussion has demonstrated that the small worlds of Québec, Scotland and Bavaria have become increasingly distinct from the Canadian, UK and German party structures since Elkins and Simeon first introduced the idea almost thirty years ago. This distinctiveness is reflected in the development of distinct regional party systems, the regionalisation of statewide parties, and the increasing importance of the territorial dimension in structuring party competition. 
To take our first indicator, the paper revealed that there is incongruence between the regional and statewide party systems, and also between the other regional party systems in the state. This form of asymmetry was evident in the number and type of parties competing at the statewide and regional levels, the regionalization of voting behaviour, and the existence of a nationalist party in the regional party system. A second indicator was the increasing importance of territory in party competition. The existence of nationalist parties has forced statewide parties to adopt stronger positions on the constitutional status of the region. For example, the success of the PQ and SNP were largely responsible for the regionalisation and constitutional radicalisation of the Quebec Liberals and Scottish Labour. Yet nationalist parties themselves appeared to have rejected outright independence. Instead, they visualise the self-determination of their territory within wider economic and political frameworks. Thus, the PQ opts for Québec independence, but whilst maintaining an economic and political partnership with the rest of Canada; the CSU seeks to negotiate Bavarian autonomy within German and European structures; and the SNP supports independence in a Europen context.

The third indicator of small world political distinctiveness at the regional level was the adaptation of statewide parties to multi-level politics. In general it was found that regional branches of statewide parties have sought to position themselves as regional parties that aim to protect regional interests. But parties have adopted a variety of strategies to appeal to regional electorates. For instance, the Québec Liberals, Scottish Labour, Conservatives and LibDems have all pursued more autonomist strategies in the region, seeking greater organisational independence and control over policy development. The Bavarian Greens, SPD and FDP are moving on a similar track, but have sought to retain close cohesion across the federal parties whilst carving out a more distinct regional voice, thus maintaining a more federalist strategy. And the NDP in Québec felt the need to secede altogether and embed itself more firmly in regional politics. As such, none of the parties have become more 'centralised' in response to multi-level politics. There are a number of explanations for these developments. For Rayside, divergence between federal and provincial parties on the issue of regional questions is to be expected as 'political actors tied to one or the other level of government would be expected to defend the jurisdictional prerogatives of that level' (Rayside 1978: 503). Carty and Eagles (2003: 5) have maintained that it was natural for parties to tailor their appeals to meet the 'tastes and concerns' of the local electorate. Another explanation, explored in this paper, is that regional branches have been forced to adopt stronger territorial positions to compete with nationalist parties. Furthermore, in many cases statewide parties have not just responded to the local political environment, but are actually products of that environment with deep historical roots, i.e. Scottish Labour, the Québec Liberal Party, the Scottish Conservative and Unionist Party and the Bavarian SPD.

This analysis challenges the view that party competition has become more nationalised in much of the industrialised West (Caramani 2004; Chhibber and Kollman 2004), implying a homogenisation of political structures and processes across the statewide level. In federal, devolved and multi-level political systems, party systems have emerged at the regional level that are quite distinct from that at the state level, regional elections display different dynamics of party competition, national parties have become increasingly distinct and regionalised, and territory has (re)emerged as a major cleavage in party politics. States are seeing the rebirth of small worlds within their borders that can claim to constitute distinct, self-contained societies. This indicates that territory has not disappeared from party politics, nor been ironed out by the 'nationalisation' of party politics. Rather, there is every indication that territory is becoming an even more pronounced feature of advanced democratic states, in Canada and beyond. 


\section{References}

Bélanger, É. (2008) 'The 2007 Provincial Election in Quebec', Canadian Political Science Review, $2 / 1$.

Bradbury, J. (2006), 'British political parties and devolution: adapting to multi-level politics in Scotland and Wales', in: D. Hough and C. Jeffery (eds) Devolution and Electoral Politics (Manchester: MUP).

Brown, A., McCrone, D., Paterson, L. and Surridge, P. (1998) The Scottish Electorate. The 1997 General Election and Beyond (Basingstoke: Macmillan Press).

Caramani, D. (2004) The Nationalization of Politics: The Formation of National Electorates and Party Systems in Western Europe (Cambridge: CUP).

Carty, R.K. (2001) 'Canadian party politics in the new century', Journal of Canadian Studies, Winter.

Carty, R.K. (2006) 'Political Turbulence in a Dominant Party System', PSOnline.

Carty, R.K., W. Cross and L. Young (2000) Rebuilding Canadian Party Politics, (VancouverL UBC Press).

Chhibber, P. and K. Kollman (2004) The Formation of National Party Systems: Federalism and Party Competition in Canada, Great Britain, India, and the United States (Princeton: PUP).

Dawson, R.M. (1957) The Government of Canada (Toronto: UoT Press).

Deschouwer, K. (2003), Political parties in multi-layered systems, European Urban and Regional Studies, 10/3.

Detterbeck, K. and E. Hepburn (2009—forthcoming) 'Party Politics in Multi-Level Systems. Party responses to new challenges in European democracies' in J. Erk and W. Swenden (eds) Exploring New Avenues of Comparative Federalism Research (London and NY: Routledge).

Detterbeck, K. and W. Renzsch (2003), Multi-level electoral competition: the German case, European Urban and Regional Studies, 10/3.

De Winter, L. and H. Türsan (1998) Regionalist Parties in Western Europe, (London and NY: Routledge)

Downs, A. (1957) An Economic Theory of Democracy (New York: Harper).

Eagles, M. and R.K. Carty (2003) 'Small Worlds and Local Strongholds in Canadian Federal Politics: Deviations from General Patterns of Party Support in the 200 Election', paper presented to CPSA, Halifax May 30 - June 1.

Elkins, D. 'The Structure of Provincial Party Systems' in D. Elkins and R. Simeon (1980) Small Worlds: Provinces and Parties in Canadian Political Life (Toronto: Methuen).

Epstein, L. (1964) 'A Comparative Study of Canadian Parties', American Political Science Review, 58/1.

Fabre, E. (2008) 'Party Organization in a Multi-level system. Party Organizational Change in Spain and the UK', Regional \& Federal Studies, 18/4.

Geekie, J. and Levy, R. (1989) 'Devolution and the Tartanisation of the Labour Party', Parliamentary Affairs, Vol. 42, No. 3, July.

Gidengil, E., A. Blais, R. Nadeau and N. Nevitte (1999) 'Making Sense of Regional Voting in the 1997 Canadian Federal Election: Liberal and Reform Support Outside Quebec', Canadian Journal of Political Science, 32/2.

Hepburn, E. (2006) 'Scottish autonomy and European integration: the response of Scotland's political parties' in J. McGarry and M. Keating (eds) European Integration and the Nationalities Question (Routledge: London and New York). 
Hepburn, E. (2008) 'The Neglected Nation: The CSU and the Territorial Cleavage in Bavarian Party Politics', German Politics, 17/2

Hepburn, E. (2008-forthcoming) 'Substate Strategies in response to Europeanizing and Globalizing trends' in Pompeo Della Posta, Milica Uvalic and Amy Verdun (eds) Globalization, Development and Integration, Basingstoke: Palgrave Macmillan.

Hopkin, J. (2003), Political decentralisation, electoral change and party organisational adaptation. A framework for analysis, European Urban and Regional Studies, 10(3).

Hopkin, J. and J. Bradbury (2006) 'British Statewide Parties and Multilevel Politics', Publius: The Journal of Federalism, 36:1.

Hough, D. and C. Jeffery (2006) (eds) Devolution and electoral politics (Manchester: MUP). James, P. (1996) The Politics of Bavaria, Aldershot; Avebury

Jeffery, C. (1997), ed., The Regional Dimension of the European Union. Towards a Third Level in Europe?, (London, Portland OR: Frank Cass).

Keating, M. (1996a), Nations Against the State: The New Politics of Nationalism in Quebec, Catalonia and Scotland, (London: Macmillan).

Keating, M. (1998), The New Regionalism in Western Europe: Territorial Restructuring and Political Change, (Cheltenham, UK: Edward Elgar).

Lynch, P. (1996), Minority Nationalism and European Integration, (Cardiff: UoW Press).

McEwen, N. (2004), The Evolution of Labour's Territorial Strategy in Scotland and Wales, paper presented to PSA Territorial Politics conference, Glasgow, 7-9 January.

Maor, M. (ed) (1997), Political Parties and Party Systems, (London and NY: Routledge).

Mintzel, A. (1990), 'Political and Socio-economic Developments in the Postwar Era: The Case of Bavaria 1945-1989' in K. Rohe (ed.) Elections, Parties and Political Traditions. Social Foundations of German Parties and German Party Systems 1867- 1987, (New York and Oxford; Berg).

Mintzel, A. (1999) Die CSU-Hegemonie in Bayern. Strategie und Erfolg, Gewinner und Verlierer (Passau: Rothe).

Mitchell, J. (1996) Strategies for Self-Government. The Campaigns for a Scottish Parliament, (Edinburgh: Polygon).

Ostermann, R. (1994) Freiheit für den Freistaat : kleine Geschichte der bayerischen SPD, Essen : Klartext-Verlag.

Padgett, S. and Burkett, T. (1986) Political parties and elections in West Germany: the search for a new stability (London : C. Hurst).

Rayside, D. (1978) 'Federalism and the Party System: Provincial and Federal Liberals in the

Province of Quebec', Canadian Journal of Political Science, 11/3.

Rokkan, S. and Urwin, D. (1983), Economy, Territory, Identity. Politics of West European Peripheries, (London: Sage Publications).

Sani, G. and G. Sartori (1983) 'Polarisation, Fragmentation and Competition in Western Democracies' in H. Daalder and P. Mair (eds), Western European Party Systems. (London: Sage).

Sartori, G. (1976) Parties and party systems: a framework for analysis (Cambridge: CUP).

Smiley, D. (1972) Canada in Question: Federalism in the Seventies (Boston: Little Brown).

Storper, M. (1995), 'The Resurgence of Regional Economies, 10 Years Later', European Urban and Regional Studies, 2/3, pp.191-221.

Tanguay, A.B. (2004) 'Sclerosis or a Clean Bill of Health? Diagnosing Québec's Party System in the Twenty-first Century' in A. Gagnon (ed) Québec: State and Society (Peterborough: Broadview Press, $3^{\text {rd }}$ Edn). 
Thorlakson, L. (2006), Party systems in multi-level contexts, in: D. Hough and C. Jeffery (eds.), Devolution and electoral politics (Manchester: MUP).

Tilly, C. (1975), The Formation of National States in Western Europe, (Princeton, NJ:

Princeton University Press).

Unger, I. (1979) Die Bayernpartei. Geschichte und Struktur 1945-1957 (Stuttgart: Deutsche. Verlags-Anstalt).

Van Biezen, I. and J. Hopkin (2006), Party organisation in multi-level contexts, in: D. Hough and C. Jeffery (Eds.), Devolution and electoral politics (MUP).

Wilson, A. (2007) 'Federalisation of the state and multi-level party organisation in Spain and Italy', paper presented to PSA, Bath, 11-13 April.

\footnotetext{
${ }^{\mathrm{i}}$ Please note that these are only approximate graphs of party positions on the ideological and territorial dimensions. Research will be conducted by the author in 2008-10 using a coding procedure derived from the comparative manifestos project (CMP) methodology to more accurately chart the positions of regional parties on the left-right and independence-integration axes. The positioning of parties as shown is based on the author's qualitative analysis of election manifestos for the political parties, in addition to interviews with party spokespeople.
} 